\title{
Glycosylation Gap in Gallstone Patients
}

\author{
Dr. Amed Tariq Hamed ${ }^{a}$, Prof. Dr. Muzahm Al-khyatt ${ }^{b}$, Dr. Muhammad A. Alkataan ${ }^{c}$, Dr. Israa Al-banaa ${ }^{c}$ \\ a Department of Surgery, Al-Jumhory Teaching Hospital, Mosul, ${ }^{b}$ Nineveh University, Mosul, ${ }^{c}$ College of Pharmacy, \\ University of Mosul, Mosul, Iraq. Correspondence: Ahmed Tariq Hamed. aths72@yahoo.com.
}

(Ann Coll Med Mosul 2019; 41 (1): 86-90).

Received: 15 ${ }^{\text {th }}$ Apr. 2018; Accepted: $19^{\text {th }}$ Mar. 2019.

\section{ABSTRACT}

Background: Gall stones are one of the commonest biliary diseases. Interest in the formation and clinical management of the disease dates back to ancient times. Gall stones continue to be one of the major health problems in the world today, although the exact number of patients is unknown, because there are no signs and symptoms related to the disease when there are no complications. The majority of the patients are diagnosed incidentally. However, some patients come with acute complication of gall stones. Gall stones are classified into; cholesterol gall stones, pigment gall stones, and mixed gall stones. However, all stones even pure cholesterol gall stones usually contain bilirubin (conjugated and unconjugated bilirubin) and cholesterol. Aim: To determine the changes in glycosylation gap and glycation profile and the relation of this change to the changes in age and BMI on the measured parameters.

Patients and methods: Serum samples were collected from 40 individuals included in this work. They are divided into 2 groups. The first group included 20 apparently healthy individuals (10 males and 10 females). The second group included 20 individuals ( 5 males and 15 females) with Gall stone diagnosed in out-patient Clinic at Al-Jamhoory General Hospital and Neinawa private Hospital. Gall stone patients with metabolic diseases, infections and other inflammatory diseases were excluded.

Results: The study demonstrated a significant elevation in serum glucose, mean blood glucose, serum fructosamin, measured and predicated $\mathrm{HbAc1}$ in GS patients in comparison with controls. Regarding the relation between age and measured parameters, the study showed a non-significant correlation between age and measured parameters in the control group, while in GS group there were a significant correlation $(r=$ $0.05)$ between ages and predicted HbAc1 and BMI ( $1 \leq 0.03)$. Regarding the relation between BMI and measured parameters, the study showed a significant correlation between measured parameters and BMI in GS individuals, while in control group only serum glucose and MBG in control group $(r=0.01)(p \leq 0.01)$ with MBI.

Conclusion: The study shows that there is a significant change in glycosylation gap and glycation profile in gall stone patients.

Keywords: Glycosylation, gall stones, HbAc1, Fructosamin.

$$
\begin{aligned}
& \text { فجوة الكليكوسيلشن عند مرضى حصى المرارة }
\end{aligned}
$$

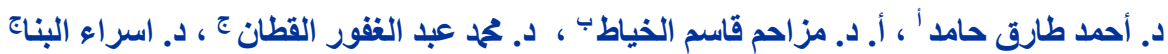

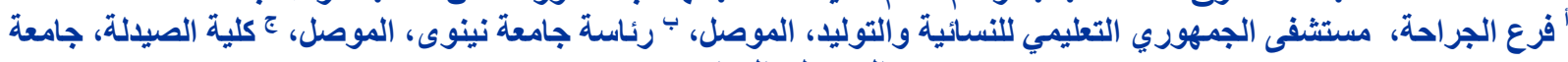

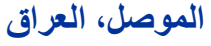

المقدمة: تعتبر حصاة المرارة من أهم الأمر اض التي تصيب الجهاز الصفر اوي ويعود الإهتمام بكيفية تكوينها وعلاجها الى فترة

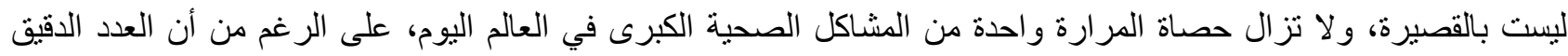

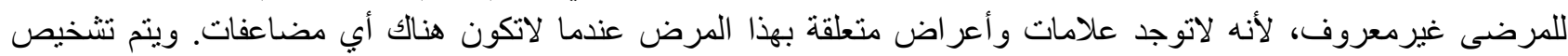

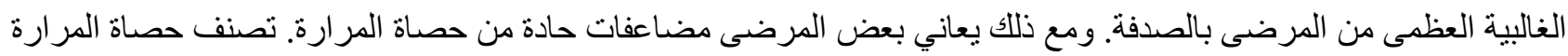




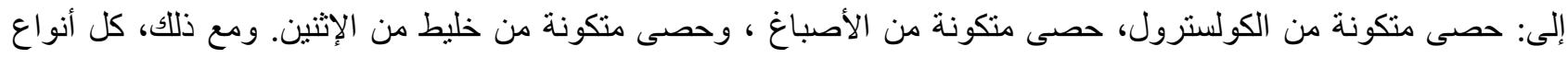

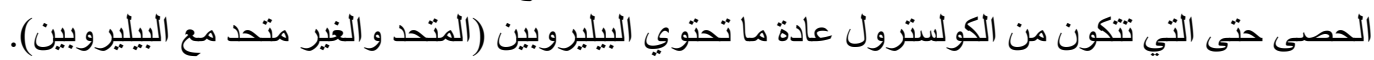

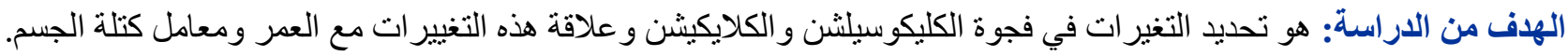

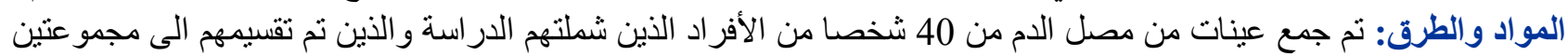

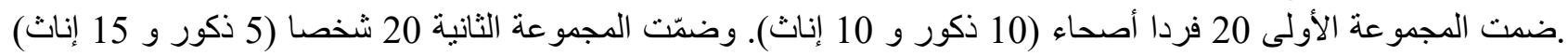

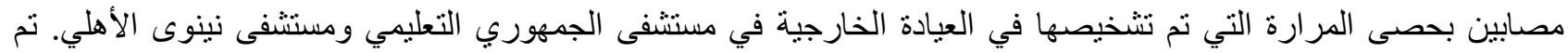

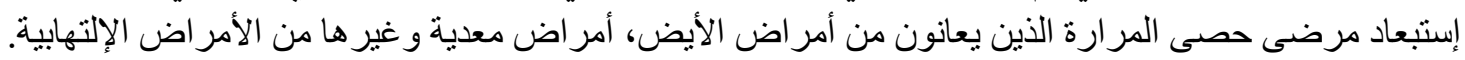

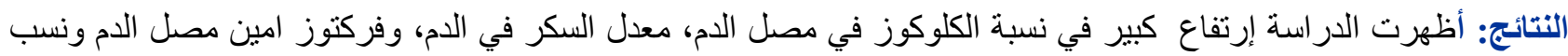

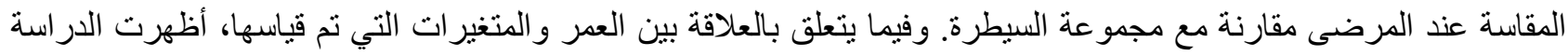

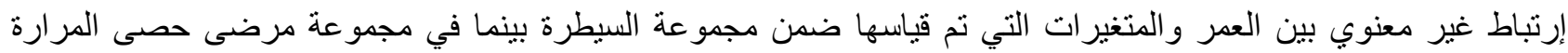

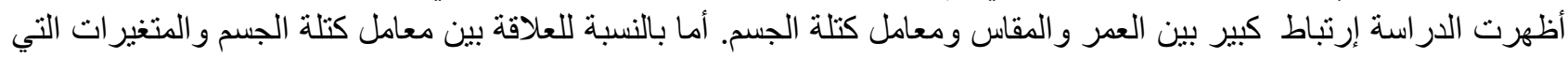

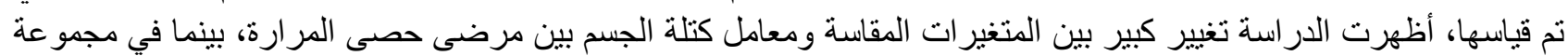

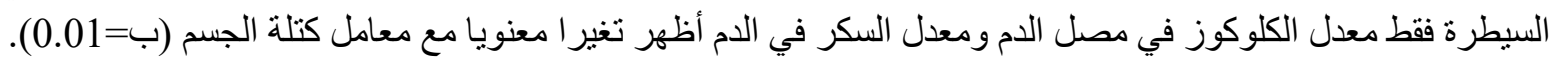

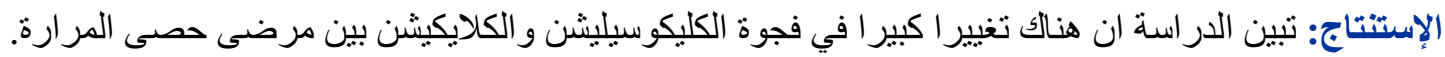

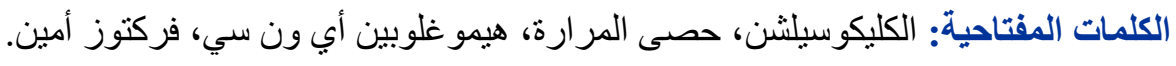

\section{INTRODUCTION}

$\mathrm{G}$ all stones are one of the commonest biliary diseases. Interest in the formation and clinical management of the disease dates back to ancient times. Gall stones continue to be one of the major health problems in the world today, although the exact number of patients is unknown, because there are no signs and symptoms related to the disease when there are no complications. The majority of the patients are diagnosed incidentally ${ }^{1}$. However, some patients come with acute complication of gall stones ${ }^{2}$.

Gall stones are classified into; cholesterol gall stones, pigment gall stones, and mixed gall stones. However, all stones even pure cholesterol gall stones usually contain bilirubin (conjugated and un conjugated bilirubin) and cholesterol ${ }^{2}$.

The prevalence of gall stones continues to rise with age, and it is higher in women than men. This may be due to the increase of cholesterol content in the bile by the effect of estrogen 2. Many hypotheses explain the reasons that can lead to gall stones, most of them may have a relation to lipid metabolism ${ }^{3,4}$.

Glycosylation is a non-enzymatic process in which proteins react with reducing sugar molecules causing impair of their function and change of their characteristics ${ }^{5}$. Glycosylation usually occurs in diabetes, aging and many other diseases where accumulation of glycosylation end products involve in pathogenesis of these diseases and their complications ${ }^{6}$.

Glycated $\mathrm{HbAc1}$ result from non-enzymatic concentration depen-dent covalent bonding of glucose to $\mathrm{Hb}$ within the erythrocytes, thereby $\mathrm{HbAc1}$ is a good indicator for glycemic control over long period 2-3 month and also its good indicator for intracellular glycation process ${ }^{7-10}$.

The extracellular glycation process can also be evaluated using serum fructosamin, a glycated end product of serum protein ${ }^{7}$. Fructosamin is a measure of average glycemic control over a shorter period 2-3 week and its plasma concentration is much more stable than that of glucose itself and much more easier to measure than true mean blood glucose (MBG), which requires contagious blood glucose monitoring ${ }^{8-11}$. Glycosylation gap (GG) defined as the value that results from subtraction of direct measured $\mathrm{HbAc1}$ value minus the predicted $\mathrm{HbAc} 1$ value obtained from equation using another indicator of glycemic control, fructosamin $(F A)^{7}$.

$G G$ is use as clinical research tool for evaluating physiological sources of variation that affects glycemic control and it can also be used as a tool to define the direction of glycosylation process ${ }^{6-13}$.

The aim of this study is to determine the changes in glycosylation gap and glycation profile and the relation of this change to the changes in age and $\mathrm{BMI}$ on the measured parameters. 


\section{PATIENTS AND METHODS}

This study was conducted during the period from October 2011 to January 2013 in the department of clinical pharmacy - college of pharmacy in cooperation with the department of surgerycollege of medicine; under approval of scientific and ethics committee in Neinawa health office. Serum samples were collected from 40 individuals whose included in this work they are divided into 2 groups.

The first group included 20 apparently healthy individuals (10 males and 10 females). The second group included 20 individuals (5 males and 15 females) with Gall stone whose diagnosed in outpatient Clinic at Al-Jamhoory General Hospital and Neinawa private Hospital. Gall stone patients with metabolic diseases, infections and other inflammatory diseases were excluded.

Serum fasting glucose was assayed by glucose oxidase/peroxides colorimetric method ${ }^{14}$, FA by NBT-spectrophotometric method ${ }^{15}$ and $\mathrm{HbAc} 1 \%$ measured by Chromatographicspectrophotometric method ${ }^{16}$, While mean blood glucose (MBG) predicted $\mathrm{HbAc1}$ and Glycosylation gap were calculated using equations ${ }^{13,17}$.

$M B G=1.76 \times(\mathrm{HbAc} 1)-3.67 \mathrm{mmol} / \mathrm{L}$

$\mathrm{P}-\mathrm{HbAc1}=0.017 \times \mathrm{FA}+1.61$

$\mathrm{GG}=\mathrm{M}-\mathrm{HbAc} 1-\mathrm{P}-\mathrm{HbAc1}$

Data are presented as mean $\pm S D, 2$-sample ttest was used to compare between measured parameters in test group and control group. The relationship between age or BMl and the measured parameters were determined by Pearson correlation.

\section{RESULTS}

The study demonstrated a significant elevation in serum glucose, mean blood glucose, serum fructosamin, measured and predicated $\mathrm{HbAc1}$ in GS patients in comparison with controls Table 1.

The glycosylation gap shows a significant increase in GS patients when compared to controls.
Table 1:

\begin{tabular}{lcc}
\hline \multicolumn{1}{c}{ Parameter } & Control & $\begin{array}{c}\text { Gallstone } \\
\text { patients }\end{array}$ \\
\hline $\begin{array}{l}\text { Serum fasting } \\
\text { glucose }\end{array}$ & $4.40 \pm 0.91$ & $5.7 \pm 0.2^{*}$ \\
$\begin{array}{l}\text { Serum } \\
\text { fructosamin }\end{array}$ & $237 \pm 11.01$ & $423 \pm 33.8^{*}$ \\
$\begin{array}{l}\text { Measured } \\
\text { HbAc1 }\end{array}$ & $5.58 \pm 0.33$ & $7.11 \pm 0.48^{*}$ \\
$\begin{array}{l}\text { Predicted } \\
\text { HbAc1 }\end{array}$ & $5.59 \pm 0.3$ & $8.71 \pm 0.42^{*}$ \\
$\begin{array}{l}\text { Mean blood } \\
\text { glucose }\end{array}$ & $6.32 \pm 0.51$ & $8.70 \pm 0.51^{*}$ \\
$\begin{array}{l}\text { Glycosylation } \\
\text { Gap }\end{array}$ & $-0.02 \pm 0.332$ & $-1.74 \pm 0.244^{*}$ \\
\hline * P<0.05 & & \\
\end{tabular}

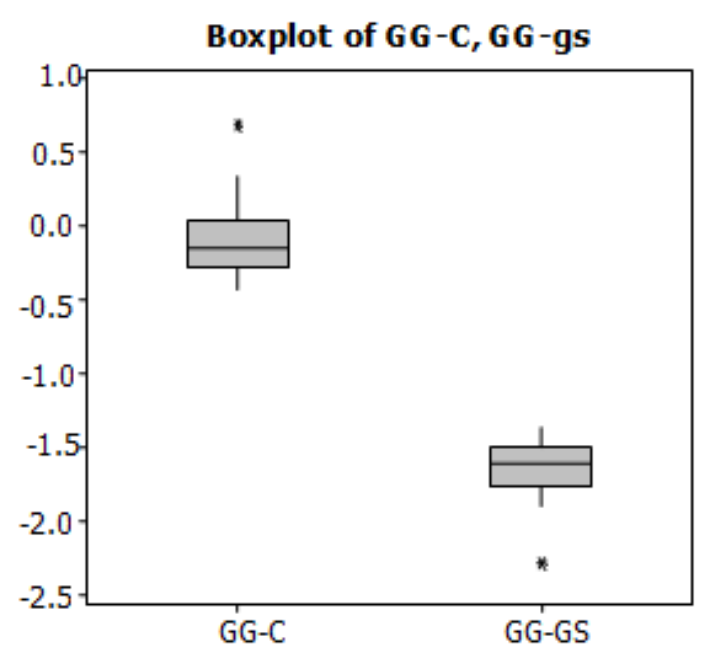

Figure 1. Glycosylation gap in gallstone and controls.

Regarding the relation between age and measured parameters, the study showed nonsignificant correlation between age and measured parameters in the control group, while in GS group there were a significant correlation $(r=0.05)$ between ages and predicted $\mathrm{HbAc} 1$ and $\mathrm{BMI}$ ( $p \leq$ 0.03).

Regarding the relation between BMI and measured parameters, the study showed a significant correlation between measured parameters and BMI in GS individuals, while in control group only serum glucose and MBG in control group $(r=0.01)(p \leq 0.01)$ with MBI. 


\section{DISCUSSION}

Glycosylation gap is defined as the difference between the measured $\mathrm{HbAc1}$ and $\mathrm{HbAc1}$ predicted from glucose serum protein based on the $\mathrm{HbAc1}$ from regression equation

$G G=H b A c 1$ measured-HbAc1 predicted. Glycation has both physiological and pathophysiological significance ${ }^{18}$.

Gallstone disease is one of the most prevalent gastrointestinal Diseases with a substantial burden to health. Etiology and pathogenesis of cholesterol gallstones are still not well defined, and strategies for prevention and efficient non-surgical therapies are missing ${ }^{19}$.

Based on the obtained results, it can be clearly stated that the glycosylation gap has elevated level in GS patients when compared to control group; furthermore, it demonstrated a significant correlation $(r=0.05)$ between age, predicted $\mathrm{HbAc1}$ and BMI $(p \leq 0.03)$ among GS group ${ }^{20}$.

Thus we can hypothesize that significance correlation between predicted $\mathrm{HbAc1}$ and $\mathrm{BMI}$ in GS may contribute to the increase in $G G$. This is in accordance with AL-kataan who described a significance correlation between MBG, serum fructoseamine, and $\mathrm{GG}$ with $\mathrm{BMI}$ in obese individuals ${ }^{1}$. as well as it may be associated with relation to an increase in insulin resistance that in turn associated with intravascular hyperglycemia and hypertriglyceridemia that associated with obesity and agrees with the results described by Ruderman et al.,Resnick et al and Boden et al. ${ }^{21-23}$

The study showed a significant difference in mean blood glucose between GG patients and control group which is in accordance with ALKataan et al who demonstrated that there is a significance increase in fasting glucose $(P<0.01)$ in GS patient prior and posterior of Cholecystectomy ${ }^{24}$.

The study also revealed that the relation between age, BMI and measured parameters shows non- significance correlation between age and measured parameter in control group.

\section{CONCLUSION}

The study shows that there is a significant change in glycosylation gap and glycation profile in gall stone patients.

\section{RECOMMENDATION}

The researchers recommend further work on glycation end products, ROS formation and nitroreductases activity to define the relation between GSD and glycemic control in this group of patients before and after treatment.

\section{REFERENCES}

1. AL-Kataan MA. Lipid Measurement and Some Biochemical Changes Pre- and Post- Cholecystectomy in gall stone patients. MSc thesis In Clinical Biochemistry, College of Medicine, University of Mosul, Iraq. 2005;pp 1-3.

2. Sherlock S, Dooly J. Diseases of the liver and biliary system Blackwell, Malden, London. 2002; PP 706.

3. Ahmad A, Cheug RC, Keeffe. Management of Gall stones and Their Complications. Amer Fam Phys 2000; 15;61(6):1673-80,1687-8.

4. Buckingham IJ. ABC of diseases of liver, pancreas and biliary system, BMJ. 2001; 322: 91-4.

5. Smart LM, Howie F, Young J, et al. Comparison of fructosamine with glycated hemoglobin and plasma proteins as measures of glycemic control. Diabetes Care 1988;11:433-436.

6. Nathan M, Singer E, Hurxthal K, et al. The clinical information value of the glycosylated hemoglobin assay. N Engl J Med 1984;310:341-346.

7. Nayak A, Holland M, Nevill A, et al. Evidence for consistency of glycation gap in diabetes. Diabetic Care 2011;34(8):1712-1716.

8. Cohen R, Holmes $\mathrm{Y}$, Chenier T, et al. Evidence for Independent Heritability of the Glycation Gap (Glycosylation Gap) Fraction of $\mathrm{HbAc1}$ in Non diabetic Twins Diabetes Care 2006; 29(8): 1739-1743.

9. Lachin J, Genath S, Nathan D, et al. The hemoglobin index is not an independent predictor of the risk of micro vascular complications in diabetes control and complications. Diabetes 2007;56:1913-1922.

10. Robert M, Holmes R, Thomas C, et al. Discordance between $\mathrm{HbAc1}$ and Fructosamin evidence for a glycosylation gap and its relation to diabetic nephropathy. Diabetes Care 2003;26(1):163-167.

11. Baker R, O Connor $P$, Metcalf $A$, et al. Clinical usefulness of estimation of fructosamin concentration as screening test for diabetes mellitus. $\mathrm{Br}$ Med $\mathrm{J}$ 1983;288:863-867.

12. Baker R, Johnson N, Scott J. Serum fructosamin concentration in patients with type II diabetes mellitus during changes in management. $\mathrm{Br}$ Med $\mathrm{J} 1984 ; 287$ : 1484-1486.

13. Lester $\mathrm{E}$. The clinical value of glycated hemoglobin and glycated plasma proteins. Ann ClinBiochem 1989;26:213-219.

14. Lotta A, Turner K. Evaluation of trinder's glucose oxidase method for measuring glucose in serum and urine. ClinChem 1975;21:1754-1760.

15. Baker R, Patricia M, Roger N, et al. Use of proteinbase slandered in automated colorimetric determination of fructosamine in serum Clin.Chem. 1985;31:15501554.

16. Bisse $E$, Abraham C. New less temperature sensitive micro chromatographic method for the separation and 
quantitation of glycated hemoglobin using a non-cyanide buffer system. Chromatog 1985;344:81-91

17. Raja Reddy $\mathrm{P}$, Reethesh RP, Mahesh V: The association between estimated average glucose levels and fasting glucose levels in rural tertiary care centre.Global J Medicine Public Health,2013;2(1):1-5.

18. Anwar S, Younus $H$. Prevention of non-enzymatic glycosylation (glycation): implication in the treatment of diabetic complication.Int J Health Sci.2016,1(2):261-277. 19. Einarsson C, Marschall H-U. Gallstone disease. J Internal Med.2007;261:529-542.

20. Babikr WG, Alshahrani ASA, Hamid HGM, Khear $\mathrm{AHM}$, Shalayel MHF. The correlation of $\mathrm{HbA} 1 \mathrm{c}$ with body mass index and HDL-cholesterol in type 2 diabetic patients.Biomed Research 2016;27(4):1280-1283.
21. Ruderman N, Chisholm D, Pi-Sunyer X, Shneider S. Perspective diabetes:The metabolically obese, normal weight individual revisited. Diabetes.1998;47:699-713. 22. Resnick W, Moonka R, Stiens SA, Resnick WJ, McDonald JM,Eubank WB, etal. The prevalence and natural history of gallstones in spinal cord injured patients. J Am Coll Surg.1999;189(3):274-281.

23. Boden G, Lebed B, Schatz M, Homko C, Lemieux S. Effects of acute changes of plasma free fatty acids on intramyocellular fat content and insulin resistance in healthy subjects. Diabetes.2001;50:1612-1617.

24. Al Kataan MA, Alkyatt MK., Dalla Bashi A. Some serum lipid profile and glucose levels Pre- and PostCholecystectomy. Journal of the Bahrain Medical Society 2010; 22(1):18-22. 